\title{
PROFESIONALISME APARAT DAN KAPASITAS KELEMBAGAAN DALAM PELAYANAN PUBLIK DI PROVINSI JAWA BARAT
}

\author{
Rahman Mulyawan \\ Dede Mariana \\ Program Studi Ilmu Pemerintahan \\ Fakultas Ilmu Sosial dan Ilmu Politik Universitas Padjadjaran \\ e-mail: rahmanmulyawan@yahoo.com
}

\begin{abstract}
ABSTRAK
Makalah ini mengkaji pada pengaruh profesionalisme pegawai terhadap kualitas pelayanan publik. Posisi pegawai, terlebih yang berada di front line, merupakan pihak yang paling dekat dengan pelanggan/masyarakat. Merekalah yang paling tahu tentang kebutuhan masyarakat. Selain itu, pegawai merupakan sumber daya yang memiliki kapasitas yang lebih besar bila dibandingkan dengan keberadaan seorang pimpinan, karena dalam aktifitas pemberian pelayanan sehari-hari, keberadaan pimpinan sering kali berada pada posisi yang jauh dari pelanggan, sehingga apabila pegawai tidak diberdayakan, maka kapasitas yang ada menjadi tidak termanfaatkan secara maksimal. Oleh karena itu sudah seharusnya pegawai diberikan kemampuan dan dibangkitkan kemauannya dalam bekerja, diberikan keleluasaan untuk bertindak dan mengambil sikap yang diperlukan agar dapat memberikan layanan yang maksimal kepada pelanggan/masyarakat.
\end{abstract}

Kata Kunci: Profesionalisme Aparat, Pegawai Pemerintah, Pelayanan Publik

\section{ABSTRACT}

This manuscript researched about the influence of government officers to public services quality. Standing of officers moreover in the front line is the persons who closer to the customer. They know about what the customer's need. Besides that, they are resources who are had capacity bigger than the existence of a leader. because the activity giving daily services, where leaders often are in a put away from the customers, so that if officers are not empowered, then the capacity there not using optimally. Therefore, officers should have been given to ability and willingness raised in the works, given the freedom to act and take a stand that is required in order to provide maximum service to customers or community.

Keywords: Apparatus professionalism, Government officer, Public service

\section{PENDAHULUAN}

Ditinjau dari segi konstitusinya, pelayanan publik merupakan proses

$$
\begin{aligned}
& \text { menuju tujuan utama dibentuknya } \\
& \text { suatu negara, yakni bagaimana } \\
& \text { mewujudkan kesejahteraan bagi }
\end{aligned}
$$


rakyatnya. Dalam konteks Indonesia, tujuan dari dibentuknya pemerintahan negara dan daerah sebagaimana termaktub dalam Pembukaan UndangUndang Dasar 1945 utamanya adalah untuk memajukan kesejahteraan umum dan mencerdaskan kehidupan bangsa.

Pelayanan publik merupakan pengejawantahan dari amanat konstitusi tersebut untuk memberikan pelayanan kepada warganegaranya. Dua aktor penting dari pelayanan publik menyangkut, adalah itu pemerintah sebagai penyedia barang atau jasa dan warganegara atau masyarakat sebagai pengguna barang atau jasa. Bidang yang disediakan oleh pemerintah merupakan bidang yang esensial, yaitu kebutuhan dasar masyarakat dalam menjalankan kehidupannya sehari-hari.

Rendahnya mutu pelayanan yang diberikan oleh aparatur menjadi citra buruk pemerintah di tengah masyarakat. Bagi masyarakat yang pernah berurusan dengan birokrasi selalu mengeluh dan kecewa terhadap tidak layaknya aparatur dalam memberi pelayanan. Oleh karena itu penyebab kegagalan utama dalam melaksanakan orientasi pelayanan publik ini (jelasnya, tugas desentralisasi) adalah: kuatnya komitmen budaya politik yang bernuansa sempit; kurangnya tenagatenaga kerja yang terlatih dan trampil dalam unit-unit lokal; kurangnya sumber-sumber dana untuk melaksanakan tugas dan tanggung jawab; adanya sikap keengganan untuk melakukan pendelegasian wewenang; dan kurangnya infrastruktur teknologi dan infrastruktur fisik dalam menunjang pelaksanaan tugas-tugas pelayanan publik.

Selain itu kegagalan dari pelayanan publik ini disebabkan karena aparat (birokrasi) tidak menyadari adanya perubahan dan pergeseran yang terjadi dalam budaya masyarakatnya dari budaya yang bersifat hirarkhis ke budaya yang bersifat individual, dari budaya yang bersifat fatalis, ke budaya yang bersifat egaliter. Pelayanan publik yang modelnya birokratis cocok untuk budaya masyarakat hirarkhis; pelayanan publik yang modelnya privatisasi cocok untuk budaya masyarakat individual (yang anti hirarkhis); pelayanan publik yang modelnya kolektif cocok untuk budaya masyarakat fatalis (yang mendukung budaya hirarkhis dan anti budaya individu); sedangkan pelayanan publik yang modelnya memerlukan pelayanan cepat dan terbuka cocok untuk budaya masyarakat egaliter (yang anti budaya hirarkhis, anti budaya individu dan anti budaya fatalis). Saat ini, kecenderungannya mengatakan bahwa masyarakat Jakarta sudah memasuki era budaya masyarakat egaliter, oleh karenanya bentuk pelayanan publik yang cocok adalah model pelayanan cepat dan terbuka.

Proses perubahan pembudayaan ini harus disebarluaskan atau disosialisasikan secara merata kepada masyarakat, dicarikan rekruitmen 
tenaga-tenaga birokrat yang

profesional, dipahami atau diartikulasikan secara tepat dan benar, ditumbuhkembangkan sebagai kepentingan masyarakat secara umum, dan dikomunikasikan secara dialogis. Hasil dari proses pembudayaan diharapkan mampu menciptakan pengambilan keputusan/kebijaksanaan yang benar, menciptakan terbentuknya kelompok pelaksana kerja yang efektif, dan terciptanya tim pengawasan yang bertindak jujur dan obyektif. Pada akhirnya, proses ini berujung pada proses internalisasi kepribadian dan sinergi ekonomi masyarakat sebagai basis utamanya.

Sofian Effendi

menyebutkan beberapa faktor yang menyebabkan rendahnya kualitas pelayanan publik (di Indonesia) antara lain adanya:

1) Konteks monopolistik, dalam hal ini karena tidak adanya kompetisi dari penyelenggara pelayanan publik non pemerintah, tidak ada dorongan yang kuat untuk meningkatkan jumlah, kualitas maupun pemerataan pelayanan tersebut oleh pemerintah;

2) Tekanan dari lingkungan, dimana faktor lingkungan amat mempengaruhi kinerja organisasi pelayanan dalam transaksi dan interaksinya antara lingkungan dengan organisasi publik;

3) Budaya patrimonial, di mana budaya organisasi penyelenggara pelayanan publik di Indonesia masih banyak terikat oleh tradisitradisi politik dan budaya masyarakat setempat yang seringkali tidak kondusif dan melanggar peraturan-peraturan yang telah ditentukan.

Keadaan di atas membuat masyarakat sebagai pengguna pelayanan publik menjadi tidak terpuaskan, sehingga masyarakat enggan mengurus segala sesuatu yang berhubungan dengan birokrasi pemerintah. Selanjutnya masyarakat mencari jalan pintas dengan cara melanggar peraturan yang ada, di sinilah proses Korupsi, Kolusi, dan Nepotisme (KKN) dimulai. Pelayanan menjadi komoditas yang diperjualbelikan oleh aparatur untuk memperkaya dirinya, menjadi tawar menawar dalam pemberian pelayanan kepada masyarakat yang seharusnya menjadi tugas dan tanggung jawabnya.

Dalam kaitannya dengan proses reformasi yang sedang berjalan, maka peranan dan eksistensi aparatur sebagai unsur utama penyelenggaraan pemerintahan, baik yang berada di pusat maupun di daerah dituntut untuk memahami kondisi obyektif lingkungan masyarakat yang sedang berubah. Dalam kondisi sekarang ini, pemerintah dituntut untuk melakukan perubahan total pada sikap, perilaku, tindakan kearah budaya kerja yang efisien, hemat, bersahaja serta anti KKN. Dengan perubahan yang dilakukan tersebut diharapkan mampu mewujudkan harapan masyarakat akan 
adanya pelayanan publik yang lebih adil, profesional, efisien, efektif, transparan dan bebas dari unsur KKN serta meningkatkan kualitas pengembangan kapasitas kelembagaan.

Berdasarkan latar belakang penelitian tersebut di atas, dapat diidentifikasikan beberapa faktor yang menyebabkan belum optimalnya kapasitas kelembagaan dan profesionalnya aparat di Provinsi Jawa Barat dalam pelayanan publik, karena:

1) Birokrasi pemerintah Provinsi Jawa Barat masih belum optimal dalam menjalankan fungsi pelayanan umum;

2) Perilaku kepemimpinan dalam penyelenggaraan pelayanan publik belum terfokus pada melayani;

3) Profesionalisme pegawai dalam memberikan pelayanan masih belum baik;

4)

$\begin{array}{lr}\text { Belum } & \text { optimalnya } \\ \text { pengembangan } & \text { kapasitas }\end{array}$

kelembagaan;

Dengan demikian pegawai harus profesionalisme sehingga dapat menyesuaikan dengan kebutuhan masyarakat, tepatnya perubahan sosial diikuti dengan perubahan manajemen pemerintahan. Para pegawai pada dasarya media atau instrument penyelenggaraan pemerintahan yang bekerja untuk kepentingan masyarakat secara keseluruhan atau merupakan jembatan antara kepentingan masyarakat dan kepentingan pemerintah. Para pegawai harus professional dalam melayani masyarakat karena profesionalisme pegawai merupakan arah serta tujuan dari tata kelola pemerintahan yang baik.

Profesionalisme pegawai merupakan salah satu dari 10 prinsip tata pemerintahan yang baik, yang dibuat oleh UNDP (United Nations Development Program), berdasar aspek kelembagaan : yaitu 1. Partisipasi, 2.Penegakan Hukum, 3.Transparansi, 4.Akuntabilitas, 5. Persamaan, 6.Tanggap pada tuntutan masyarakat, sedangkan dari aspek manusia nya $: 7$. Visioner, 8.Profesionalisme, 9.Efektif dan efisien, dan 10.Pengawasan. Secara konseptual hubungan antar prinsip bersifat mutualistik dan saling mendukung.

\section{A. Profesionalisme Aparat dan Pelayanan Publik di Bappeda Provinsi Jawa Barat}

Bappeda Provinsi Jawa Barat sebagai Organisasi Perangkat Daerah (OPD) diatur melalui Peraturan Gubernur Jawa Barat nomor 17 Tahun 2015 tentang Tugas Pokok, Fungsi, Rician Tugas Unit dan Tata Kerja Badan Perencanaan Pembangunan Daerah Provinsi Jawa Barat, memiliki tanggung jawab dalam perencanaan dengan tugas pokok yang meliputi melaksanakan perumusan dan pelaksanaan kebijakan teknis perencanaan pembangunan dan penyusunan serta pelaksanaan kebijakan perencanaan pembangunan 
Daerah. Dalam menyelenggarakan tugas pokok tersebut, Bappeda mempunyai beberapa fungsi :

1. Penyelenggaraan perumusan dan penetapan kebijakan teknis perencanaan pembangunan daerah;

2. Penyelenggaraan kesekretariatan, penelitian/pengkajian, pengendalian dan evaluasi, fisik, ekonomi, sosial dan budaya, pemerintahan serta pendanaan pembangunan;

3. Penyelenggaraan data dan informasi pembangunan serta mengkomunikasikan hasil-hasil perencanaan pembangunan daerah untuk peningkatan mutu dan akuntabilitas perencanaan;

4. Penyelenggaraan koordinasi dan sinkronisasi

perencanaan pembangunan Daerah dengan nasional serta Kabupaten/Kota.

Jika dicermati, sedikitnya ada tiga implikasi penting terhadap perencanaan pembangunan daerah, yaitu: (i) pemerintah daerah memiliki kewenangan yang semakin luas untuk mengatur dirinya sendiri; (ii) pemerintah daerah semakin dituntut untuk mampu mengelola dan memanfaatkan semua potensi daerah melalui pengembangan kreatifitas, inisiatif, prakarsa, dan partisipasi dari seluruh komponen masyarakat; dan (iii) semakin besarnya tuntutan masyarakat akan akuntabilitas publik, pemerintahan yang bersih, transparansi, keterbukaan, pelayanan publik, dst.
Berbagai implikasi di atas telah mengakibatkan tanggung jawab dan kewenangan Bappeda juga semakin besar dan luas. Bappeda, disamping dituntut untuk tetap melaksanakan fungsi dasarnya, yaitu mengembangkan proses perencanaan, mengimplementasikan, serta melakukan monitoring dan evaluasi atas perencanaan pembangunan daerah, juga dituntut untuk menyusun kerangka makro rencana pembangunan daerah, menentukan strategi dan prioritas program pembangunan daerah, mengidentifikasi dan mengelola potensi daerah, mengembangkan sumber-sumber alternatif pembiayaan pembangunan daerah, mengembangkan kerjasama vertikal dan horizontal, merangsang partisipasi masyarakat, dan lain-lain.

Namun patut disayangkan bahwa struktur organisasi Bappeda hampir tidak mengadaptasi atau melakukan proses penyesuaian (adjustment process) atas membengkaknya tanggung jawab dan kewenangan tersebut. Jika diamati, struktur organisasi Bappeda, hampir tidak mengalami perubahan berarti. Kalaupun terjadi perubahan, nampaknya hanya sebatas perubahan nomenklatur jabatan. Sama sekali tidak ada perubahan yang berlangsung secara diametral.

Tentu saja, agak sulit mengharapkan Bappeda lebih optimal jika struktur organisasinya masih kental dengan nuansa struktural, hirarkial, dan 
birokratis. Struktur organisasi seperti itu mungkin sesuai untuk lembaga teknis - katakanlah dinas dan kantor tetapi tentu saja tidak cocok untuk lembaga "think-tank" seperti Bappeda. Proses kreatifitas berpikir - sesuatu yang amat diperlukan di Bappeda sulit tumbuh di lingkungan kerja yang mengedepankan struktur dengan pola kaku "atasan-bawahan" dan bekerja berdasarkan atas "instruksi-juklakjuknis".

Dengan beban kerja yang relatif cukup tinggi, Bappeda di hadapkan kepada tantangan masa depan yang lebih kompleks. Sehingga dengan peran strategis yang diemban, Bappeda dituntut untuk dapat lebih rensponsif dan proaktif dalam menyelesaikan permasalahanpermasalahan pembangunan di Provinsi Jawa Barat. Bappeda diharapkan mampu beradaptasi dengan cepat dan tepat, tidak hanya dalam konteks kekinian melainkan juga melakukan antisipasi kejadian yang akan datang. Dengan demikian perlu disusun struktur organisasi Bappeda Provinsi Jawa Barat yang ideal dan proporsional, yang di dalamnya ada unsur lini dan unsur staf, yang semuanya harus sinergi dari Top manajer, midle manajer sampai dengan lower manajer yang diimplementasikan oleh Pejabat Eselon II, Pejabat Eselon III dan Pejabat Eselon IV Bappeda.

Namun harapan tersebut diatas terindikasi sulit untuk terlaksana mengingat UU No 5/2014 tentang Aparatur Sipil Negara (ASN) memiliki program untuk penghapusan jabatan eselon III, IV dan V (di Bapeda Provinsi Jawa Barat tidak memiliki jabatan eselon $V$ ). Para pegawai dari tiga jenjang eselon itu nantinya bakal menduduki sebagai pegawai fungsional. Ada dua hal pokok yang akan mengalami perubahan setelah UU ASN diberlakukan. Kedua hal itu terkait struktur kelembagaan dan penghapusan jabatan eselon III sampai V. Tiap SKPD hanya terdapat unsur kepala, sekretaris dan tata usaha. Dan konsekuensinya jabatan eselon III, IV dan $\mathrm{V}$ dihapus.

Apabila memperhatikan kondisi di atas, maka eselonisasi yang terdapat di lembaga Bappeda Provinsi Jawa Barat adalah sebagai berikut : Eselon II (1 orang), Eselon III (7 orang) dan Eselon IV (19 orang) dengan rincian seperti pada tabel di bawah ini. 
Tabel 1

Jabatan dan Eselonisasi Di Bappeda Provinsi Jawa Barat (Perda Mo. 3 Tahun 2014 tentang SOTK)

\begin{tabular}{|c|c|c|}
\hline Nomor & Jabatan & Eselon \\
\hline 1 & Kepala & II \\
\hline 2 & Sekretaris & IIIa \\
\hline 3 & Subbag Perencanaan dan Program & \multirow{3}{*}{ IVa } \\
\hline 4 & Subbag Umum & \\
\hline 5 & Subbag Keuangan & \\
\hline 6 & Bidang Pengendalian dan Evaluasi & IIIa \\
\hline 7 & $\begin{array}{l}\text { Subbid Pengendalian dan Evaluasi Fisik, Ekonomi dan } \\
\text { Pendanaan Pembangunan }\end{array}$ & \multirow[t]{2}{*}{ IVa } \\
\hline 8 & Subbid Pengendalian dan Evaluasi Sosial Bidaya & \\
\hline 9 & Bidang Fisik & IIIa \\
\hline 10 & Subbid Tata Ruang dan Lingkungan Hidup & \multirow{2}{*}{ IVa } \\
\hline 11 & Subbid Infrastruktur Wilayah & \\
\hline 12 & Bidang Ekonomi & IIIa \\
\hline 13 & Subbid Pertanian & \multirow[b]{2}{*}{ IVa } \\
\hline 14 & Subbid Dunia Usaha, Industri, Perdagangan dan Pariwisata & \\
\hline 15 & Bidang Sosial Budaya & IIIa \\
\hline 16 & Subbid Kependudukan dan Kesehatan & \multirow{2}{*}{ IVa } \\
\hline 17 & Subbid Agama, Pendidikan dan Kebudayaan & \\
\hline 18 & Bidang Pemerintahan & IIIa \\
\hline 19 & Subbid Aparatur Politik dan Hukum & \multirow{2}{*}{ IVa } \\
\hline 20 & Subbid Kerjasama Pembangunan & \\
\hline 21 & Bidang Pendanaan Pembangunan & IIIa \\
\hline 22 & Subbid Anggaran Pendapatan dan Belanja Daerah & \multirow{6}{*}{ IVa } \\
\hline 23 & Subbid Non Anggaran Pendapatan dan Belanja Daerah & \\
\hline 24 & UPTB Pusdalisbang & \\
\hline 25 & Subbag Tata Usaha & \\
\hline 26 & Kasie Pelayanan Informasi dan Komunikasi & \\
\hline 27 & Kasie Data dan Analisa & \\
\hline
\end{tabular}

Sumber : Bappeda Provinsi Jawa Barat (2016) 
Penghapusan jabatan eselon III sampai $\mathrm{V}$ itu dimaksudkan untuk efisiensi kinerja pegawai pemerintahan. Mereka nantinya hanya menjadi pegawai fungsional. Perubahan inilah yang harus dipersiapkan Pemerintah Provinsi/Kabupaten/Kota.

Tidak dipungkiri selama ini jabatan fungsional masih dipandang sebelah mata. Bahkan setiap kali para pegawai eselon ditawari menjadi pegawai fungsional cenderung gengsi, sebab jabatan itu dinilai seolah nonjob. Padahal tenaga fungsional sangat diperlukan dalam pelaksanaan tugas-tugas pokok organisasi.

Jabatan fungsional ini seperti auditor, tenaga arsiparis, peneliti, perencana, pranata komputer, statistik, pranata laboratorium dan penguji kendaraan bermotor. Selama ini jabatan fungsional peneliti masih langka dan dipandang sebelah mata, karena memang belum banyak dikenal. Padahal, peneliti mutlak diperlukan keberadaannya di setiap satuan kerja.

Jabatan peneliti juga sangat strategis, mengingat tidak ada persyaratan angka kredit untuk menempati jabatan ini. Saat ini tengah dipersiapkan program yang nantinya mengharuskan masing-masing unit SKPD memiliki tenaga fungsional perencana. Diupayakan, ke depan pejabat fungsional pun bisa menduduki struktural asalkan punya legalisasi kompetensi jabatan (atau lolos dalam lelang jabatan).

\section{B. Permasalahan Profesionalisme Aparat}

1. Mekanisme Koordinasi

Diakui atau tidak, salah satu titik lemah dalam struktur organisasi Bappeda selama ini adalah belum optimalnya mekanisme kerja dan koordinasi antar bidang. Bidang yang ada dalam struktur organisasi Bappeda cenderung bekerja sesuai dengan bidang tugasnya masingmasing, tanpa merasa perlu untuk mengetahui tugas ataupun berkoordinasi dengan bidang lainnya. Pembidangan seringkali diterjemahkan dan diimplementasikan secara kaku dan penuh sekat. Akibatnya, terjadi fragmentasi, pengkotak-kotakan, dan egoisme bidang dalam tubuh Bappeda. Kondisi ini tentu saja amat tidak kondusif bagi pekerjaan perencanaan. Sebab, bagaimanapun, pekerjaan perencanaan adalah sebuah pekerjaan yang bersifat integratif, komprehensif, dan holistik. Masalah ini, sekali lagi, hanya bisa diatasi jika struktur organisasi Bappeda lebih berciri "divisionalisasi".

Lalu, bagaimana pula gambaran koodinasi antara Bappeda dengan Dinas dan lembaga teknis daerah (Badan dan Kantor)? Nampaknya, juga tidak jauh berbeda. Koordinasi berlangsung dengan intensitas yang rendah dan tanpa arah yang jelas. Bahkan seringkali terjadi pertikaian - khususnya dalam hal penetapan program dan kegiatan antara Bappeda dengan Dinas dan 
lembaga teknis daerah (Badan dan Kantor). Ini terjadi akibat ketidakjelasan (atau ketiadaan) platform perencanaan pembangunan daerah. Sebab, ketiadaan platform perencanaan seperti itu mengakibatkan tidak adanya parameter untuk menentukan mengapa misalnya suatu program disetujui dan mengapa program lainnya dieliminasi.

Saat ini, di kalangan pemerintah daerah berkembang pandangan yang mengatakan bahwa kesetaraan eselonisasi antara Bappeda dengan Dinas dan Badan menjadi sumber penyebab mengapa Bappeda tidak optimal mengemban fungsi koordinasi perencanaan. Namun, pandangan ini tentu saja tidak sepenuhnya valid, sebab di zaman dulu ketika eselonisasi Bappeda satu level di atas Dinas, fungsi koordinasi perencanaan juga tidak sepenuhnya berjalan secara optimal. Oleh karena itu, menurut hemat penulis, efektifitas fungsi koordinasi perencanaan, bukan ditentukan oleh faktor eselonisasi, tetapi lebih ditentukan oleh faktor kewibawaan dan kredibilitas Bappeda sebagai institusi perencanaan pembangunan daerah, yang lahir dari kemampuannya untuk merumuskan platform perencanaan yang akurat.

\section{Kapasitas dan Kompetensi Aparat \\ Dalam kaitannya dengan implementasi kewenangan yang dimiliki oleh Bappeda, salah satu kekhawatiran banyak kalangan adalah kualitas sumber daya manusia (SDM)}

daerah yang tidak cukup memadai untuk melaksanakan sejumlah kewenangan dan tanggung jawab yang didelegasikan kepadanya. Meskipun anggapan tersebut direspon oleh daerah sebagai stigma yang sengaja dihembuskan agar pola sentralistik dapat tetap dipertahankan, atau paling tidak, skala pemberian otonomi dapat lebih diminimalkan, namun secara jujur harus diakui bahwa kualitas SDM aparat yang dipunyai daerah, khususnya daerah kabupaten/kota, secara umum memang relatif masih rendah. Ini setidaknya bisa diamati dari tingkat pendidikan, pengetahuan, pengalaman, wawasan, motivasi, etos kerja, kualifikasi, kapasitas, dan kompetensi.

Jika ditelusuri kebelakang, ini bukan sepenuhnya kesalahan daerah. Sistem pemerintahan sentralistik yang dilaksanakan selama lebih dari tiga dekade, turut berkontribusi terhadap rendahnya kualitas SDM aparat di daerah. Dalam sistem ini, pemerintah pusat melakukan intervensi pada hampir semua dimensi kehidupan. Bahkan sistem ini telah menciptakan dominasi pemerintah pusat atas pemerintah daerah dan dominasi pemerintah atas masyarakat. Pemerintah daerah hanya dijadikan alat untuk melayani kepentingan pemerintah pusat di daerah. Karenanya, sistem tersebut telah menghambat berlangsungnya proses belajar, sekaligus menumpulkan daya inisiatif dan kreatifitas pemerintah daerah dalam menjalankan aktifitas 
pembangunan dan memberikan pelayanan kepada masyarakat. Aparat pemerintah daerah hanya dicekoki dengan beragam instruksi, arahan, dan petunjuk (juklak dan juknis). Karenanya pekerjaan cenderung dilaksanakan secara "teknismekanistis".

Mengubah mentalitas aparat dari budaya petunjuk ke budaya inisiatif tentu saja bukanlah pekerjaan mudah. Dibutuhkan berbagai bentuk intervensi strategis secara sistemik dan berkelanjutan, terutama yang berkaitan dengan pengembangan kapasitas kelembagaan dan aparatur. Diharapkan, dengan adanya berbagai bentuk intervensi strategis tersebut, akan lahir aparat pemerintah daerah yang "cemerlang", yang sanggup memadukan dan menjaga keseimbangan antara pekerjaan teknis dengan non-teknis, antara loyalitas dengan integritas, antara rutinitas dengan kreatifitas.

Sedangkan secara lokal, rendahnya kualitas SDM aparat, juga disebabkan oleh sistem rekruitmen, pola mutasi dan promosi, pemberiaan kesempatan mengikuti pendidikan dan pelatihan, lingkungan kerja, dan lain-lain. Oleh karena itu, untuk penguatan kelembagaan Bappeda ke depan, kesemuanya itu perlu mendapat pembenahan, khususnya dalam hal independensi Bappeda dalam mengatur dan menata seluruh perangkat kelembagaannya secara internal. Pembenahan dimaksud, antara lain:
Pertama, rekruitmen staf. Mungkin sudah saatnya dipikirkan, rekruitmen staf sepenuhnya menjadi kewenangan Bappeda sendiri, sehingga benar-benar sesuai dengan kebutuhan intern Bappeda. Bagaimanapun, pekerjaan perencanaan bukan semata-mata pekerjaan "teknis", tetapi lebih merupakan pekerjaan "intelektualitas". Amat sulit mengharapkan Bappeda menjadi sebuah lembaga yang berwibawa dan kredibel jika hanya didukung oleh staf yang masuk kategori "biasa". Amat naiff mengharapkan Bappeda tumbuh menjadi lembaga perencana yang kuat jika lembaga-lembaga teknis justru lebih menguasai filosofi perencanaan daripada orang-orang Bappeda. Oleh karena itu, rekruitmen dan pembinaan staf seyogyanya mendapat perhatian serius di masa depan.

Kedua, mutasi dan promosi. Selama ini, penempatan jabatan eselon di Bappeda hampir selalu bersifat dropping dan hanya disesuaikan dengan kepangkatan, dan bukan didasarkan atas kapasitas, kompetensi, dan kualifikasi. Akibatnya, seringkali ada staf yang menempati jabatan eselon di Bappeda yang tidak pernah sama sekali terlibat sebelumnya dalam kegiatan perencanaan. Dan pada saat yang sama, seringkali pula ada staf yang sudah dikader dan dibina dengan baik dalam hal perencanaan, namun karena pengaturan job, harus dipindahkan (mutasi) ke instansi lain yang sama 
sekali tidak ada kaitannya dengan perencanaan. Ke depan, sudah saatnya dikembangkan pola jabatan karir di lingkungan Bappeda, yang mana hal tersebut di satu sisi dapat menjadi reward bagi staf yang potensial dan berprestasi, dan di sisi lain akan memperkuat kelembagaan Bappeda dari segi pengembangan staf.

Ketiga, pengembangan staf dan lingkungan kerja. Aparat Bappeda harus didorong dan diberi kesempatan yang seluas-luasnya untuk meningkatkan kompetensinya, baik melalui jalur pendidikan formal maupun jalur pelatihan. Pemberian kesempatan harus berlaku bagi siapa saja dan tidak lagi ditentukan oleh faktor klise: like and dislike. Disamping itu, kegiatan in-house training juga perlu dibudayakan di lingkungan Bappeda. Mereka yang baru pulang dari mengikuti pendidikan dan pelatihan misalnya, wajib hukumnya untuk membagi pengetahuan yang diperolehnya kepada seluruh aparat Bappeda. Diskusi berkala juga perlu lebih diintensifkan, dimana aparat Bappeda secara bergilir menyampaikan bahan presentasi, khususnya mengenai isuisu aktual pembangunan dan perencanaan. Upaya seperti ini, disamping dapat meningkatkan semangat kolektifitas, membangun kerjasama tim, meningkatkan kualitas aparat, juga potensial menurunkan tensi persaingan di kalangan staf.
3. Sistem dan Metode

Agar Bappeda dapat menjalankan tugas pokok dan fungsinya secara optimal, maka sistem dan metode perencanaan yang dipraktekkan selama ini oleh Bappeda nampaknya juga perlu mendapat perhatian. Meski pola metode perencanaan yang dipraktekkan selama ini merupakan kombinasi antara model top-down dan bottomup, namun nuansa top-down nampak lebih kental, bukan hanya karena alasan pembiayaan (anggaran) tetapi juga karena tingkat validitas usulan kegiatan dari bawah dinilai masih relatif rendah. Yang terjadi kemudian, kepercayaan masyarakat terhadap forum-forum seperti Musbangdes untuk tingkat desa, Temu Karya untuk tingkat kecamatan, Rakorbang untuk daerah kabupaten/kota, dan seterusnya, dari waktu ke waktu kian memudar, bahkan cenderung mengarah ke sikap skeptis. Sejak beberapa tahun yang lalu, sesungguhnya telah muncul kesadaran baru di kalangan masyarakat, bahwa forum-forum tersebut tidak lagi cukup efektif untuk menjadi sebuah wahana bagi perumusan berbagai program dan kegiatan yang betul-betul berbasis pada kebutuhan masyarakat. Forum tersebut hanya sekedar untuk melegitimasi proses dan mekanisme perencanaan, tanpa pernah sanggup untuk benar-benar mengartikulasikan aspirasi dan kepentingan masyarakat.

Oleh karena itu, melanggengkan pola perencanaan yang telah terbukti memiliki sejumlah 
kelemahan dan telah melahirkan sikap skeptis di kalangan masyarakat, bukanlah sebuah sikap dan tindakan yang bijak. Beberapa daerah yang mencoba "keluar" dari pola perencanaan konvensional dan mengembangkan sendiri sistem dan metode perencanaan pembangunannya yang sesuai dengan kondisi lokalitasnya, tetap patut diapresiasi. Bagaimanapun, daerahdaerah tersebut setidaknya telah berusaha untuk melakukan adaptasi atas perubahan dinamika lingkungan strategis dan mengakomodasi tuntutan-tuntutan baru yang tumbuh dan berkembang dalam masyarakat yang semakin dinamis.

Pengembangan struktur organisasi yang lebih bersifat "divisionalisasi" (bukan departementasi) merupakan sebuah struktur yang lebih mengedepankan pada pencapaian output dan outcomes melalui pola kerja tim yang tidak dibatasi oleh sekat-sekat jabatan dan pangkat. Sebuah struktur yang bekerja berdasarkan pendekatan "integratif-sinergis". Sebuah struktur yang memberi ruang bagi setiap anggota organisasi - serendah apapun jabatan dan pangkatnya - untuk ikut berkontribusi dalam pekerjaan organisasi. Sebuah struktur yang mengapresiasi prestasi kerja dan kemudian memberi reward berdasarkan prestasi kerja tersebut. Dalam sistem divisionalisasi, pemimpin harus bertindak sebagai konduktor dari sebuah orkestra: menjamin agar semua elemen yang otonom bercampur bersama-sama secara harmonis menuju tujuan dan cita-cita bersama.

Ke depan, model bottom-up planning dengan penekanan pada perencanaan partisipatoris (partisipatory planning) nampaknya menjadi sebuah keniscayaan. Berbagai konsep perencanaan partisipatif yang dewasa ini telah dan sedang dikembangkan, katakanlah Partisipatory Rural Appraisal (PRA), Rapid Rural Appraisal (RRA), Partisipatory Learning and Action (PLA), Partisipatory Local Social Development (PLSD), Perencanaan Partisipatif Pembangunan Masyarakat Desa (P3MD), sudah saatnya diimplementasikan dalam berbagai perumusan program dan kegiatan pembangunan. Bagaimanapun, pendekatan seperti itu diyakini sungguh-sungguh melibatkan masyarakat, mulai dari tahapan perencanaan, pelaksanaan, pengorganisasian, dukungan sumberdaya, hingga tahapan evaluasi.

\section{Wacana Penghapusan Eselon III dan IV \\ Kritik dan ketidakpuasan} terhadap kinerja Badan Perencanaan Pembangunan Daerah (Bappeda) sebagai institusi yang bertanggung jawab atas perencanaan pembangunan daerah, sudah lama terdengar. Kritik dan ketidakpuasan tersebut muncul karena Bappeda dinilai gagal mengemban fungsi dan tugas pokoknya, yaitu menyusun kebijakan perencanaan pembangunan 
daerah. Buruknya kualitas perencanaan yang dihasilkan oleh Bappeda menjadi salah satu dari sekian banyak indikator untuk menilai kegagalan tersebut. Kegagalan ini terjadi, menurut penilaian berbagai kalangan , karena Bappeda lebih fokus pada kegiatan administrasi perencanaan dan seremonial pembangunan daripada kegiatan fungsional perencanaan.

Dalam beberapa tahun terakhir, terutama sejak desentralisasi dan otonomi daerah (selanjutnya disingkat destoda) mulai diimplementasikan, kritik tersebut bahkan kian ekstensif. Bappeda dinilai tidak cukup responsif dan adaptif terhadap berbagai tuntutan baru yang menyertai proses destoda, katakanlah demokratisasi, akuntabilitas publik, pemerintahan yang bersih, transparansi, partisipasi, kualitas pelayanan publik yang lebih baik, dst. Bappeda juga dianggap tidak banyak melakukan perubahanperubahan institusional dan mindset guna merespon pergeseran paradigma dan pendekatan perencanaan pembangunan, misalnya dari sentralisasi ke desentralisasi, dari topdown planning ke bottom-up planning, dari long-range planning ke strategic planning, dari budaya petunjuk ke budaya partisipasi, dari perilaku aktor ke fasilitator, dst. Kesemuanya ini nampaknya masih sebatas retorika dan belum sepenuhnya tercermin dalam keseluruhan proses perencanaan pembangunan daerah. Bahkan pola pikir dan cara pandang lama masih cukup kental mewarnai proses formulasi perencanaan pembangunan daerah. Dalam konteks ini, mungkin benar apa yang pernah dikemukakan oleh Keynes beberapa dekade lampau: "Kesulitan tidak terletak dalam menemukan ide-ide baru, melainkan terletak dalam usaha melepaskan diri dari ide-ide lama yang merasuk... kedalam setiap sudut benak kita"

Atas perspektif itulah, Bappeda nampaknya membutuhkan pembenahan. Kelembagaan Bappeda harus ditata sedemikian rupa sehingga mampu bersesuaian dengan berbagai tuntutan baru yang menyertai proses destoda. Kelembagaan Bappeda harus di-redesain agar cukup adaptif dengan pergeseran paradigma dan pendekatan perencanaan pembangunan. Bagaimanapun, destoda menuntut kapabilitas kelembagaan (institutional capability) perencanaan pembangunan daerah yang lebih memadai. Dalam penghayatan saya, pembenahan harus dilakukan secara simultan dan komprehensif, mulai dari struktur organisasi, mekanisme kerja dan koordinasi, kapasitas dan kompetensi aparat, hingga sistem dan metode perencanaan. Mudah-mudahan dengan upaya seperti ini, kritik dan ketidakpuasan terhadap kinerja Bappeda akan dapat dieliminir.

Selain permasalahan di atas, terdapat fenomena semakin terus membengkaknya anggaran untuk gaji pegawai negeri Sipil (PNS), membuat 
pemerintah melakukan beberapa terobosan. Diantaranya, adalah dengan menghilangkan golongan Eselon III dan VI. Kementerian Pendayagunaan Aparatur Negara dan Reformasi Birokrasi (PAN-RB) beralasan, dihapuskannya jabatan esselon III dan IV dan memindahkannya ke jabatan fungsional agar pegawai lebih berorientasi pada pekerjaan daripada jabatan.

Penghapusan tersebut diatur dalam UU Aparatur Sipil Negara. Namun, penghapusan tersebut diharapkan tidak mengganggu kinerja instansi pemerintahan secara keseluruhan. UU Aparatur Sipil Negara perlu mendapat perhatian khusus dari Kementerian Pendayagunaan Aparatur Negara dan Reformasi Birokrasi (PAN-RB), Lembaga Administrasi Negara (LAN) dan Badan Kepegawaian Nasional (BKN) agar tidak berdampak buruk bagi instansi pemerintahan.

Wacana penghapusan golongan III dan IV, dilontarkan beberapa waktu lalu menanggapi kritikan besarnya porsi anggaran untuk belanja pegawai. Kementerian Pendayagunaan Aparatur Negara dan Reformasi Birokrasi (PAN-RB) berencana menghapus jabatan esselon III dan IV dan memindahkannya ke jabatan fungsional agar pegawai lebih berorientasi pada pekerjaan daripada jabatan. "Selama ini orang-orang lebih berorientasi mendapatkan jabatan struktural dari pada pekerjaan," jelas Wakil Menteri
PAN-RB Eko Prasojo, di Jakarta beberapa waktu lalu.

Penerapan jabatan fungsional bertujuan agar penerapan pemberian tunjangan kinerja lebih tepat sasaran. Sebab, pemberian tunjangan kinerja didasarkan pada kualitas kerja seseorang atau lembaga.

Implementasi kebijakan ini akan dilakukan diseluruh kementerian dan lembaga di Indonesia. Melalui penghapusan struktur eselon III dan IV, misalnya, jabatan eselon III setingkat kepala sub bagian atau sub bidang, eselon IV setingkat kepala seksi akan dihapuskan. "Tidak ada lagi jabatan-jabatan semacam itu. Yang ada tugas mereka, misalnya fungsi auditor, kebijakan, juru ukur, dan sebagainya," ungkapnya.

Para pejabat eselon 3 dan 4 di lingkungan Kementerian, Lembaga Pemerintah maupun Pemerintah Daerah yang jumlahnya saat ini mencapai 236.000 lebih harus bersiap-siap kehilangan jabatan, karena berdasarkan UU Aparatur Sipil Negera, Jabatan Eselon 3 dan 4 akan dihapus. UU ini tidak lagi menganut konsep eselonisasi jabatan struktural seperti yang saat ini berlaku. Menurut UU ini jabatan ada 3 (tiga) jenis jabatan yakni jabatan administrasi, jabatan fungsional dan jabatan eksekutif senior.

Jabatan administrasi terdiri dari Pelaksana, Pengawas dan Administrator. Sedangkan Jabatan fungsional terdiri dari fungsional keahlian dan fungsional ketrampilan. 
Jabatan Fungsional Keahlian

terdiri dari ahli pertama, ahli muda, ahli madya, dan ahli utama. Sementara Jabatan fungsional keterampilan terdiri pemula, terampil dan mahir.

Kelompok jabatan yang ketiga yang diinisiasi dalam UU ini adalah Jabatan Eksekutif Senior (JES). Jabatan Eksekutif Senior adalah sekelompok jabatan tertinggi pada instansi dan perwakilan. Aparatur Eksekutif Senior adalah Pegawai ASN yang menduduki sekelompok jabatan tertinggi pada instansi dan perwakilan melalui seleksi secara nasional yang dilakukan oleh Komisi Aparatur Sipil Negara (KASN) dan diangkat oleh Presiden. Jabatan Eksekutif Senior terdiri dari pejabat struktural tertinggi, staf ahli, analis kebijakan, dan pejabat lainnya yang ditetapkan dengan Peraturan Pemerintah. Pejabat struktural tertinggi yang termasuk kelompok ini adalah mulai dari Wakil Menteri, Sekjen, Dirjen sampai dengan Sekda. Didalam Naskah Akademik UU ini disebutkan bahwa Jabatan Eksekutif Senior mencakup jabatan Eselon 1 dan Eselon 2 atau yang disetarakan dalam sistem administrasi kepegawaian yang berlaku selama ini. Disebutkan bahwa jabatan eksekutif senior di daerah hanya Sekretaris Daerah, dengan kata lain jabatan eselon 2 di daerah semisal Kepala Dinas, Kepala Badan atau Kepala Kantor tidak termasuk sebagai Pejabat Eksekutif Senior, barangkali dimasukan ke dalam kelompok
Pejabat Administrasi? Walaupun konsep ini masih menyisakan persoalan; apakah semua jabatan eselon 3 dan 4 yang saat ini ada dapat digolongkan sebagai jabatan adminitrasi, seperti Kepala Balai, Kepala UPT, Camat, Lurah, dll? Apalagi kalau dinyatakan bahwa semua jabatan di bawah JES adalah "supporting staff", apakah betul pimpinan sebuah unit kerja pemerintah, terutama di daerah dapat disebut sebagai supporting staff.

Bagi organisasi kementerian tingkat pusat tentu tidak akan menjadi masalah, namun konsep ini tidak bisa diterapkan begitu saja untuk level Pemda. Organisasi Pemda memerlukan struktur dan hirarki dalam rangka penyelenggaraan pemerintahan di Daerah. Tugas-tugas tersebut bukanlah tugas-tugas adminitratif dan fungsional semata, tapi juga tugas-tugas yang memerlukan kapasitas managerial dan leadership yang handal! Tidak semua jabatan yang ada di Pemda saat ini dapat dikelompokan sebagai jabatan adminitrasi atau pun sebagai jabatan fungsional. Disamping kabar yang "mencemaskan" tersebut, terutama bagi pejabat eselon 3 dan 4 . Ada satu hal yang menarik yang diperkenalkan oleh RUU ini yakni mengenai pengisian Jabatan Eksekutif Senior! Yakni yang selama ini dikenal sebagai pejabat eselon 1 dan 2 (tidak termasuk kepala dinas daerah). Dikatakan bahwa sistem pengadaan pegawai berbasis jabatan (position based personnel 
management system) dengan cara mengadakan seleksi terbuka bagi pegawai Aparatur Sipil Negara.

Dengan sistem ini PNS dan PTTP (Pegawai Tidak Tetap Pemerintah) yang memenuhi kualifikasi dan memiliki kompetensi dapat mengikuti seleksi calon Pejabat Eksekutif Senior yang lowong. Misalnya apabila ada Jabatan Sekjen yang lowong di sebuah kementerian, semua PNS yang memenuhi kualifikasi dan kompetensi bisa mengikuti seleksi. Ketentuan ini berlaku juga bagi Pegawai Tidak Tetap Pemerintah (PTTP) atau Pegawai Kontrak bahkan individu dari kalangan swasta, asal memenuhi kualifikasi boleh mengikuti seleksi. Demikian juga seandainya ada jabatan Sekda yang lowong maka semua PNS dan Non PNS yang memenuhi kualifikasi dan memiliki kompetensi bisa mengikuti seleksi. Hal ini tentunya positif untuk benarbenar memperoleh pejabat eksekutif senior yang kompeten dan berwawasan nasional! Konon salah satu syarat kualifikasi JES adalah pernah bertugas di 3 (tiga) daerah yang berbeda. Sistem ini dapat mengeliminir intervensi politik dalam penempatan pejabat birokrasi, serta menghapus praktek-praktek negatif dalam pengangkatan pejabat seperti jual beli jabatan, pengangkatan pejabat tidak sesuai kompetensi, pemberian jabatan sebagai balas budi, dan praktek-praktek lainnya tidak sesuai dengan visi dan misi intitusi. Siapkah PNS menyongsong pemberlakuan sistem ini? Mudahmudahan UU ini menjadi langkah nyata reformasi birokrasi, bukan reformasi setengah hati, seperti yang berjalan saat ini.

Kementerian Pendayagunaan Aparatur Negara dan Reformasi Birokrasi (KemenPAN-RB) sudah menyiapkan 11 jabatan fungsional (Jabfung) utama untuk memindahkan PNS yang menduduki jabatan eselon III dan IV. Hal ini dilakukan agar pegawai tidak dirugikan dan tetap memiliki orientasi kinerja. Konsekuensinya dengan memindahkan orientasi struktural menjadi fungsional melalui pemangkasan eselon III dan IV. Dalam pemangkasan tersebut, ada beberapa hal yang harus siap dan menjadi tolok ukur di antaranya angka kredit, pola karier, dan lainlain. Diakui kalau saat ini tunjangan fungsional masih lebih rendah dibanding jabatan struktural. Akibatnya, jabatan struktural menjadi rebutan, karena tunjangannya banyak. Karena itu, tunjangan fungsional harus ditingkatkan. Harapan adanya tunjangan fungsional setara dengan structural akan menjadikan PNS tidak terpaku pada jabatan struktural saja.

Untuk lingkungan Bappeda, sangat jelas kenginan pemerintah menghapuskan eselon III dan IV agar Bappeda mampu meningkatkan profesionalisme dan kredibilitas Bappeda sebagai lembaga perencana juga untu mengoptimalkan kelompok fungsional perencana. Kelompok ini lebih diorientasikan pada tugas-tugas 
fungsional perencanaan ketimbang tugas-tugas administratif. Upaya seperti ini, disamping dapat menghilangkan kekakuan hubungan antar bidang-bidang yang ada dalam struktur organisasi Bappeda selama ini.

Salah satu penyebab munculnya masalah eselonisasi adalah karena orang-orang Bappeda lebih menyukai jalur struktural daripada jalur fungsional. Mereka merasa lebih bangga dan terhormat jika menyandang jabatan struktural (misalnya kepala bidang, eselon III, dst) daripada menyandang jabatan fungsional (misalnya perencana pertama, perencana muda, dst). Bagi orang-orang Bappeda, pencapaian karier di birokrasi lebih dicerminkan oleh posisi jabatan struktural - bukan jabatan fungsional - yang mampu diraih. Mudah dipahami kemudian mengapa jabatan struktural jauh lebih memikat dibandingkan dengan jabatan fungsional.

\section{Usulan dan Rekomendasi}

Berdasarkan uraian permasalahan dan kajian teori yang telah dikemukakan, maka dapat dikemukakan usulan dan rekomendasi sebagai berikut :

1. Struktur Organisasi Bappeda yang ideal memiliki dua alternatif bentuk yang dapat dipilih berdasarkan kebutuhan dan kemampuan, yaitu :
a. Struktur dengan mempertahankan 7 (tujuh) Bidang yang telah ada sesuai

dengan Pergub Jawa Barat nomor 17 Tahun 2015.

b. Struktur dengan perampingan bidang menjadi 4 (empat) bidang, 1 (satu) Balai dan 1 (satu) UPTB yang terdiri atas:

i. Bidang Pengendalian dan Evaluasi

ii. Bidang Ekonomi dan Pendanaan Pembangunan

iii. Bidang Sosial Budaya dan Pemerintahan

iv. Bidang Fisik

v. Balai Diklat Perencana Pembangunan

vi. UPTB Humas dan Pelayanan pada Masyarakat

2. Jabatan Struktural Eselon IV harus tetap dipertahankan, dengan alasan

a. Jabatan Struktural Low Manager yang meliputi : Kasubbid, Kasubbag, Kasie dan Kepala UPTB sangat menunjang dan mendukung optimalisasi operasionalisasi kinerja Bappeda.

b. Eksistensi low manager secara teori berlaku universal dan keberadaannya disesuaikan dengan konsep desentralisasi (otonomi) yang berbasis terhadap kemampuan dan kebutuhan daerah.

3. Jabatan Administrasi Pengawas, Jabatan Fungsional Keahlian (ahli utama, ahli madya, ahli muda dan ahli pertama) serta Jabatan Fungsional Keterampilan (penyelia, mahir, terampil dan 
pemula) harus diberlakukan di Bappeda Provinsi Jawa Barat secara bertahap dan diharapkan efektif pada Tahun 2018.

Terkait dengan upaya penghapusan jabatan eselon III dan IV di lembaga Bappeda Provinsi Jawa Barat, maka ada beberapa hal yang perlu diperhatikan oleh organisasi, antara lain:

Pertama, proses perpindahan pegawai dalam jabatan struktural, khususnya jabatan struktural eselon III dan IV, kepada jabatan fungsional tertentu, perlu ada mekanisme tertentu yang mendasari proses perpindahan jabatan yang disandang pegawai dari jabatan struktural kepada jabatan fungsional tertentu; Kedua, dilaksanakannya kajian formasi terhadap kebutuhan jabatan fungsional tertentu di lembaga Bappeda Provinsi Jawa Barat agar ada kesesuaian antara beban tugas organisasi dengan jumlah pegawai dalam jabatan fungsional tertentu yang sangat berpengaruh terhadap pengembangan kariernya;

$$
\text { Ketiga, dilaksanakannya }
$$

penyesuaian besaran tunjangan untuk jabatan fungsional tertentu yang belum sesuai dengan bobot jabatan atau dengan tunjangan jabatan fungsional tertentu lainnya diharapkan dapat mendorong motivasi kerja pegawai yang telah pindah ke jabatan fungsional tertentu;

Keempat, dilaksanakannya orientasi kepada para pegawai baru dalam jabatan fungsional tertentu dimaksudkan sebagai upaya untuk menyesuaikan keberadaan para pegawai baru dalam jabatan fungsional tertentu terhadap tugastugas barunya, sekaligus pengenalan terkait dengan pengembangan karier pada jabatan fungsional tertentu;

Kelima, dilaksanakannya pengembangan kualitas atau kompetensi pegawai dalam jabatan fungsional tertentu untuk menyesuaikan kemampuan kerja dengan tugas barunya, juga dimaksudkan sebagai upaya peningkatan kinerja pegawai tersebut.

\section{E. Daftar Pustaka}

Iriani, Enni. 2007. Kajian Kebijakan Good Local Governance Dalam Optimalisasi Pelayanan Publik: Suatu Evaluasi Implementasi Pelayanan Publik Terpadu di Kabupaten/Kota di Indonesia. Bandung: PKP2AILAN.

Ivansevich. M. John, Konopaske Robert, Matteson. T. Michael. 2007. Perilaku dan Manajemen Organisasi. Jilid 1. Jakarta: Penerbit Erlangga.

Koehler, Jerry W., Pankowski, Joseph M. 1997. Transformational Leadership in Government. Delray Beach, Florida: St. Lucie Press.

Kotter, J.P. dan Heskett. 1992. A

Force for Change: How Leadership Differs From Management. New York: Free Press.

Kouzes, James M. dan Barry Z. Posner. 1987. The Leadershio 
Challenge: How to Get Extraordinary Things Done in Organizations. San Francisco: Josset-Bass Publisher.

Kumorotomo, Wahyudi. 1992. Etika Administrasi Negara. Jakarta: PT Rajafindo Persada. . 1999. Etika Administrasi Negara. Jakarta: PT Rajafindo Persada.

Lembaga Administrasi Negara. 2003.

Tehnik Penyusunan Organisasi Berbasis Kinerja. Jakarta: LAN dan BPKP.
.2004. Modul Sistem Akuntabilitas Kinerja Instansi Pemerintah. Jakarta: LAN dan BPKP.

Light, Paul. 2008. The Pillars of High Performance: 4 Kunci Penting Menuju Perusahaan yang Sehat dan Kuat. Jakarta: PT. Buana Ilmu Komputer

Luthans, Fred. 1995. Organizational Behavior. ( $7^{\text {th }}$ eds). Singapore: Mc Graw-Hill.

Mahmudi. 2005. Manajemen

Kinerja Sektor Publik. Yogyakarta: UPP AMP YKPN. 